Article

\title{
Identifying the Planning Priorities for Green Infrastructure within Urban Environments Using Analytic Hierarchy Process
}

\author{
Yeeun Shin ${ }^{1}$, Suyeon Kim ${ }^{1}$, Sang-Woo Lee ${ }^{2} \mathbb{C}$ and Kyungjin An ${ }^{2, *(1)}$ \\ 1 Department of Forestry and Landscape Architecture, Graduate School, Konkuk University, Seoul 05029, \\ Korea; julie9276@konkuk.ac.kr (Y.S.); mdln94@konkuk.ac.kr (S.K.) \\ 2 Department of Forestry and Landscape Architecture, Konkuk University, Seoul 05029, Korea; \\ sw17311@konkuk.ac.kr \\ * Correspondence: dorian@konkuk.ac.kr
}

Received: 1 June 2020; Accepted: 6 July 2020; Published: 7 July 2020

\begin{abstract}
Urban environmental issues such as declining air quality and increasing urban heat island effects can be managed by the effective use of urban green spaces. Consequently, the importance of green infrastructure (GI) has rapidly increased over time. While the various functions of GI have been investigated in numerous studies, limited research has focused on prioritizing those factors which impact the planning and development of GI. This study used literature reviews, expert surveys, and an analytic hierarchy process methodology to identify and prioritize the critical factors influencing GI during the design and construction process to enhance the role of GI in urban areas. Experts were asked to prioritize four primary (ecological, landscape, usability, and economic factors) and 16 secondary aspects of GI design. Respondents strongly agreed on the importance of the ecological aspects of GI, while the government sector also highlighted the importance of economic concerns, such as ongoing maintenance. Results indicated that the priorities for creating GI require further analysis and mediation between stakeholders. Further empirical evidence should be accumulated regarding the functions of GI for policy implementation in design and construction.
\end{abstract}

Keywords: green infrastructure; urban open space; analytic hierarchy process; air quality; holistic planning approach

\section{Introduction}

Artificial structures are predominantly present in modern cities, making the varied roles of green infrastructure (GI) vital to the community. GI is the network of natural and semi-natural features within and between villages, towns, and cities, including street trees, green roofs, green walls, and private gardens in parks, woodlands, and surrounding rivers [1]. Elements of GI can be found in existing cities to varying degrees [2].

GI benefits the surrounding environment by improving naturalness and aesthetics. At the same time, GI benefits the community by providing amenity space. GI can be a driving force for improving quality of life and for the development of local communities. As environmental issues associated with urban areas have emerged (e.g., urban heat island effects and increased concentrations of ultra-fine particulates in the air), it is necessary to reconsider the role of GI. 
In addition to providing a connection between people and their surroundings, GI also serves important ecological and socio-economic functions. For example, it enhances naturality and increases the aesthetic value of urban open spaces, where artificial materials, such as concrete, comprise the majority of the landscape. Due to its varied role in urban infrastructure, the creation of GI requires many considerations, including cost, maintenance, and economic factors. On account of these varied, and often competing, considerations, it is important to determine the critical elements of GI creation, and to prioritize these factors during the planning and construction stages.

Previous studies have evaluated the social, economic, and psychological values provided by GI [3-5]; however, there is a lack of research regarding the factors that are considered to be important when creating GI. While the importance of GI has been clearly demonstrated, there are many aspects to consider when creating GI, including financial availability and maintenance. Aditionally, comprehensive consideration is necessary for the creation of GI's function, such as reducing air pollution and climate change adaptation, to be effective [6]. Hence, it is important to understand which factors should be considered when creating GI, to harmonize those elements of high importance, especially at the policy establishment, design, and construction stages.

GI research continues to increase with new concepts regarding the role and value of GI being developed continuously. However, there are still ambiguities in the GI concepts, terms, and effects [7]. For GI to be applied in planning and field, and to achieve the target effect, a thorough understanding of the role of GI is required. Therefore, this study aims to develop the understanding of GI through a holistic approach and priority derivation. As the complexity of the role of GI continues to develop, we aim to derive the role of GI that is currently used by experts, and discuss the role of GI in the future.

Creating urban GI requires theoretical, planning, and maintenance expertise. In reality, most GI is created by local planning authorities and landscape professionals in consideration of environmental issues, health trends, aesthetic judgment, and user opinion. Consequently, many professionals play a key role in creating GI. The aim of this study is to identify the critical factors that are important for the creation of urban green space by interviewing experts related to the field and drawing on policy limits and policy outlooks. We achieve this by using an expert survey and analytic hierarchy process (AHP) methodology.

\section{Literature Review}

\subsection{Baseline Study on GI}

Modern cities face a number of serious environmental issues, including urban heat island effects, heat waves, lack of green open space, and the deterioration of air quality. The concept of GI has emerged in response to this environmental degradation [8,9]. GI is defined as the network of open space, natural, and semi-natural features within towns and cities that provides ecological value and amenity to the community $[1,10]$. Previous studies have shown that the benefits of GI are immense. For example, GI provides the ecological benefits of enhanced air quality, adaptation to climate change, improved urban microclimates, biological habitats, species diversity, and ecological connectivity [11-13]. Furthermore, the landscape benefits of GI include the presence of natural scenery in the city, providing shades, and aesthetic pleasure [14-17], while the social benefits include health promotion, stress reduction, recreational opportunities, and increased social cohesion $[5,13,18-20]$. The multifunctional characteristics and versatility of GI warrants a comprehensive approach to GI planning and design [21,22].

Many studies have been conducted to provide a conceptual framework for GI. For example, Norton et al. [23] presented the urban GI (UGI) framework to improve the urban climate through microclimate cooling through UGI. The framework includes five stages: (1) Neighboring priorities are derived (e.g., vulnerability to urban heat island effects), (2) existing UGI is identified, (3) the cooling effects from the existing UGI are maximized, (4) city roads vulnerable to solar exposure are identified, and (5) recommendations for future UGI are made. Using these five steps, a hierarchical 
decision framework was proposed to utilize street canyons for temperature mitigation. A study by Matthews et al. [12] redefined the concept of GI for climate change adaptation. Using existing research and semi-structured interviews, they showed that GI can provide multiple climate benefits. This study highlighted the importance of academic institutions in GI planning.

Studies have also shown that the effectiveness of GI is heavily dependent on a comprehensive planning approach [23-25]. In a study of GI to manage stormwater, Porse [26] found that land use planning and the monitoring of ecological processes over time was necessary to create GI with both ecological and recreational benefits. Furthermore, Kumar et al. [11] found that citywide sustainable development was possible through effective planning considering both social and ecological effects. They also highlighted the necessity of a holistic approach to policy and decision-making in urban planning. The need for a holistic approach to sustainable GI has been reinforced in numerous studies [27,28].

Several studies have investigated the factors which are important when planning and creating a comprehensive GI strategy. For example, Haq [29] described the role of urban green space by classifying it in terms of its ecological, social, and psychological benefits. They found that, from a user perspective, accessibility and optimal quantity and quality were required to satisfy social and psychological needs. Furthermore, they found that a comprehensive approach was important for solving urban sustainability problems, and stressed the need for comprehensive research through the cooperation of stakeholders at various levels. A study by Lovell and Taylor [13] proposed the use of a multifunctional landscape framework for sustainable GI planning to optimize the functional aspects of urban green space. They considered the potential of GI in terms of social and ecological aspects, and suggested the use of specific decision-making tools during the planning process. Furthermore, they showed that considering multiple ecosystem services simultaneously could help community members, investors, and decision-makers come to some agreement regarding the best land use for a specific site. They also noted the importance of a cost-benefit analysis in the evaluation of ecosystem services in future studies. Hansen and Pauleit [28] proposed a framework considering the multifunctionality of GI. They investigated, synthesized, and evaluated the ecological and social perspectives of previous studies to develop priorities for future policy and action. These priorities can be used to improve the versatility of the GI network; therefore maximizing the benefits it provides. They concluded that the use of a quantitative approach would provide more accurate information in future studies.

\subsection{Critical Elements for the Creation of $G I$}

A keyword analysis of current research and guidelines revealed that considerations for the creation of GI could be divided into four categories (Table 1). Preservation, ecological connectivity, and climate control were the major keywords related to ecological aspects of GI $[9,13,28,30,31]$. There were few studies regarding the landscape aspects of GI; however, visual factors and visual quality were the main keywords used $[13,29,30,32]$. Usability related keywords included accessibility, social opportunity, and amenity [29-31,33,34]. In terms of economic aspects, maintenance and economic value were the main keywords [29,30,34]; however, the factors related to the cost for creating GI were rarely considered [30].

Considering all the elements of GI in an integrated approach is a complex process with practical difficulties. Accordingly, it is necessary to prioritize which aspects should be considered and planned for [14]. While the many functions and benefits of UGI have been identified, limited research has focused on prioritizing the relative importance of individual elements. In this study, we present an efficient planning framework for GI using a holistic approach. We identify factors affecting planning and UGI creation and prioritize these elements using survey data and AHP methodology. In particular, we ascertain the most important elements for creating effective UGI from landscape planning, design, and research experts, with the ultimate aim of enhancing the role of GI within urban areas. 
Table 1. Green infrastructure (GI) keywords.

\begin{tabular}{|c|c|c|c|c|}
\hline \multirow{2}{*}{ Literature } & \multicolumn{4}{|c|}{ Keywords } \\
\hline & Ecological & Landscape & Usability & Economic \\
\hline EPA, 2010 & $\begin{array}{c}\text { Site Preservation } \\
\text { protection plan } \\
\text { Ecological Connectivity } \\
\text { Climate change }\end{array}$ & Visual connectivity & $\begin{array}{l}\text { Public participation } \\
\text { Accessibility } \\
\text { Public Health improvement }\end{array}$ & $\begin{array}{l}\text { Choosing Material Synthetic } \\
\text { Turf Maintenance Planning }\end{array}$ \\
\hline Shah Md, 2011 & $\begin{array}{l}\text { Absorbing pollutant } \\
\text { preservation }\end{array}$ & $\begin{array}{c}\text { Visual screen } \\
\text { Commuting and recreation } \\
\text { place }\end{array}$ & $\begin{array}{l}\text { Diversity of land uses } \\
\text { Contribution to health } \\
\text { and active life styles in cities } \\
\text { Social opportunity }\end{array}$ & $\begin{array}{l}\text { Production and supply } \\
\text { New job creation } \\
\text { Increasing economic value }\end{array}$ \\
\hline $\begin{array}{l}\text { Lovell and Taylor, } 2013 \\
\text { Hansen and Pauleit. } 2014\end{array}$ & $\begin{array}{l}\text { Plant Biodiversity } \\
\text { Microclimate control } \\
\text { Soil infiltration } \\
\text { Carbon sequestration }\end{array}$ & Visual Quality & $\begin{array}{l}\text { Physical Activity } \\
\text { Social Capital }\end{array}$ & Production \\
\hline Martinelli et al., 2014 & & & $\begin{array}{l}\text { Fruition and accessibility } \\
\text { Bioclimate comfort }\end{array}$ & $\begin{array}{l}\text { Intervention cost } \\
\text { Maintenance requirement }\end{array}$ \\
\hline Alida Alves et al., 2018 & $\begin{array}{c}\text { Water quality } \\
\text { Biodiversity } \\
\text { Temperature reduction } \\
\text { Groundwater Recharge } \\
\text { Air quality improvement }\end{array}$ & & $\begin{array}{l}\text { Amenity and aesthetics } \\
\text { Recreation and health } \\
\text { Food security }\end{array}$ & $\begin{array}{l}\text { Rainwater Harvesting } \\
\text { Saving Energy } \\
\text { Pumping and treatment } \\
\text { reduction } \\
\text { Real estate value }\end{array}$ \\
\hline Ahern et al., 2014 & $\begin{array}{l}\text { Stormwater infiltration } \\
\text { Water quality } \\
\text { Habitat provisioning } \\
\text { Air quality } \\
\text { Urban climate } \\
\text { Carbon storage } \\
\text { and sequestration }\end{array}$ & & $\begin{array}{l}\text { Public recreation } \\
\text { Cultural service provision } \\
\text { Education service potential }\end{array}$ & Food security \\
\hline Mell, 2009 & & Creating attractive places & $\begin{array}{c}\text { Accessibility } \\
\text { Exercise and recreational } \\
\text { place } \\
\text { Social cohesion } \\
\text { Access to education } \\
\text { Regeneration } \\
\text { Linking people to local } \\
\text { heritage }\end{array}$ & \\
\hline
\end{tabular}

\section{Research Methodology: AHP}

We employed the AHP method to prioritize the elements impacting GI planning and implementation. The AHP method can reflect the multiple layered structures of the decision-making process and is commonly used for analysis in unpredictable situations requiring multiple evaluation standards. The AHP method is used for research that requires a mixed understanding. For example, $\mathrm{Xu}$ et al. [35] applied the AHP method for proper multiple criterion evaluation of green and gray infrastructure. Yang et al. [36] used the AHP method to set the criteria for selecting the key infrastructure needed to build an effective U-City. Haider et al. [37] used the AHP method to set the priorities and appropriate criteria for a flood risk management. The assessment criteria for AHP comprised a pairwise comparison matrix with coexisting technical and normative models for interpretation. The AHP was established by Saaty [38,39], and is a flexible method used to analyze multi-criteria problems by building a hierarchy for decision-making through establishing priorities [40].

The AHP process involves creating objects, choosing evaluation criteria, expert evaluation, validation, and establishing weighed values for the various elements in the GI creation process. Data for the AHP were derived from literature reviews and expert interviews. Table 2 shows GI planning elements in two tiers, primary and secondary, based on literature reviews and expert interviews. The primary tier (Tier 1) includes ecological, landscape, usability, and economic elements. Each primary category was then further classified into four secondary (Tier 2) categories.

Secondary ecological factors include climate control, air quality improvement, stormwater runoff, and ecological conservation. Secondary landscape factors include creating a featured landscape, harmonizing with the surrounding environment, providing natural elements within an urban setting, and screening. Secondary usability factors include accessibility, leisure and amenity, educational functions, and shelter. Finally, secondary economic factors include groundwork, planting, paving and other works, and maintenance cost.

Data collection was carried out over two weeks, between 1-15 September 2019. Interviewees were experts in the fields of urban planning and landscape architecture. Interview candidates were 
contacted by telephone to request their participation, and 60 experts were then emailed a link to the online questionnaire. In total, 57 completed questionnaires were received. Interviewees were from government organizations, the private sector, and academia, and had experience in policy, research, design, and construction. Table 3 provides a summary of the age, experience, and expertise of the respondents.

Table 2. Evaluation criteria for creating GI.

\begin{tabular}{|c|c|c|}
\hline Primary Criteria (Tier 1) & Secondary Criteria (Tier 2) & Description \\
\hline \multirow{4}{*}{ Ecological } & Climate control & $\begin{array}{l}\text { Reducing urban heat island effects, controlling seasonal } \\
\text { temperature and humidity }\end{array}$ \\
\hline & Air quality improvement & Reducing air pollutants such as fine and ultra-fine particulates \\
\hline & Stormwater runoff & Stormwater infiltration and filtration, reducing runoff \\
\hline & Ecological conservation & Habitat creation and protection, soil conservation \\
\hline \multirow{3}{*}{ Landscape } & Creating a featured landscape & Providing urban landmarks and aesthetic features \\
\hline & Harmonizing with the surrounding environment & $\begin{array}{c}\text { Matching GI with surrounding buildings, roads, and the } \\
\text { environment }\end{array}$ \\
\hline & Providing natural elements within an urban setting & Naturalness within gray concrete structures \\
\hline \multirow{5}{*}{ Usability } & Screening & Creating spaces and screening effects using planting \\
\hline & Accessibility & Ease of community access to the GI \\
\hline & Leisure and amenity & Supporting leisure activities such as walking and exercising \\
\hline & Educational functions & Educational programs such as working with school groups \\
\hline & Shelter & $\begin{array}{l}\text { Protection from natural hazards such as flash flooding } \\
\text { and landslides, providing shelter }\end{array}$ \\
\hline \multirow{4}{*}{ Economic } & Groundwork & Cost for groundworks \\
\hline & Planting & Cost for planting \\
\hline & Paving and other works & Cost for roads, street furniture, and facilities, etc. \\
\hline & Maintenance & Entire maintenance cost \\
\hline
\end{tabular}

Table 3. Demographic characteristics of the interviewees.

\begin{tabular}{|c|c|c|c|}
\hline \multicolumn{2}{|c|}{ Category } & No. of Respondents & Percentage \\
\hline \multicolumn{2}{|c|}{ Total } & 57 & 100 \\
\hline \multirow{2}{*}{ Sex } & Male & 35 & 61.4 \\
\hline & Female & 22 & 38.6 \\
\hline \multirow{4}{*}{ Age } & $20 \mathrm{~s}$ & 13 & 22.8 \\
\hline & $30 \mathrm{~s}$ & 17 & 29.8 \\
\hline & $40 \mathrm{~s}$ & 19 & 33.3 \\
\hline & $50 \mathrm{~s}$ & 8 & 14.0 \\
\hline \multirow{4}{*}{ Organization } & Government & 11 & 19.3 \\
\hline & Academia & 13 & 22.8 \\
\hline & Private Sector & 33 & 57.9 \\
\hline & Environment & 11 & 19.3 \\
\hline \multirow{5}{*}{ Subject } & Architecture & 1 & 1.8 \\
\hline & Landscape & 38 & 66.7 \\
\hline & Forestry & 3 & 5.3 \\
\hline & Policy & 2 & 3.5 \\
\hline & Other & 2 & 3.5 \\
\hline \multirow{5}{*}{ Experience } & Under 5 years & 18 & 31.6 \\
\hline & $6-10$ years & 10 & 17.5 \\
\hline & $11-15$ years & 10 & 17.5 \\
\hline & 16-20 years & 6 & 10.5 \\
\hline & More than 21 years & 13 & 22.8 \\
\hline
\end{tabular}

Evaluation using AHP was based on pairwise comparisons between Tier 1 and 2 questions. The total number of evaluations for Tier 1 and 2 questions was 6 and 24, respectively. The evaluation scale was a normally applied 9-point scale [41], as shown in Table 4.

The AHP pairwise comparison method can be negatively impacted by the provision of inaccurate data by the interviewees. To address this, the consistency ratio (CR) was used to validate the data. Commonly, a CR value below 0.1 is considered to be consistent, and a CR of 0.1-0.2 is acceptable [42]. Data were only used in this study if the $\mathrm{CR}$ was below 0.2. Following data validation, the importance of each criteria was ascertained based on responses from the pairwise comparisons. The geometric mean 
was then applied after the relative importance of each criteria was determined to reflect the opinions of the experts [43].

Table 4. Significance of the pairwise comparisons based on Song and Lee [41].

\begin{tabular}{|c|c|c|}
\hline Scale & Definition & Description \\
\hline 1 & Equal & Two activities have equal contribution. \\
\hline 3 & Weak & $\begin{array}{c}\text { One activity is mildly preferred over the other based on } \\
\text { experience and judgment. }\end{array}$ \\
\hline 5 & Strong & $\begin{array}{c}\text { One activity is strongly preferred over the other based on } \\
\text { experience and judgment. }\end{array}$ \\
\hline 7 & Very strong & $\begin{array}{c}\text { One activity is very strongly preferred over the other based on } \\
\text { experience and judgment. }\end{array}$ \\
\hline 9 & Extreme & $\begin{array}{c}\text { One activity is extremely preferred over the other based on } \\
\text { experience and judgment. }\end{array}$ \\
\hline $2,4,6,8$ & Median & Median comparison value based on experience and judgment. \\
\hline
\end{tabular}

\section{Results and Discussion}

\subsection{Tier 1 Evaluation}

Figure 1 shows that ecological aspects (0.387) were the most important Tier 1 criteria, highlighting the importance of providing natural elements when creating UGI. Landscape aspects $(0.266)$ were the second most important, followed by usability (0.214) and economic aspects $(0.133)$.

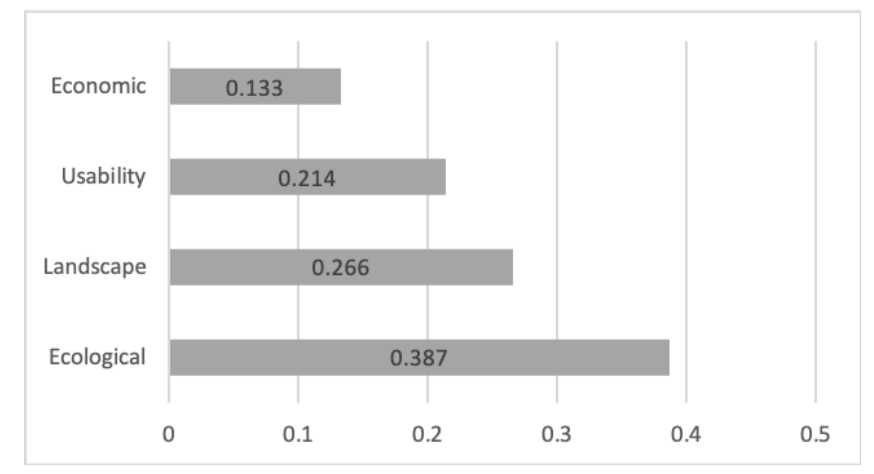

Figure 1. Relative importance of Tier 1 criteria based on survey data.

There was no difference in the ranking of Tier 1 criteria between male and female respondents (Table 5). However, more female respondents stressed the importance of ecological aspects compared to male respondents. All age groups indicated that ecological aspects were the most important consideration for UGI; however, respondents in their 20s and 30s also recognized the importance of landscape and usability aspects. In comparison, older respondents favored ecological aspects more heavily.

Respondents from academia and the private sector found that ecological aspects were the most important Tier 1 criteria, while government respondents also stressed the significance of economic factors. This reflects the importance of cost and ongoing maintenance to government respondents, who are generally responsible for the ongoing management and maintenance of UGI. Differences were also apparent based on the professional backgrounds of the respondents. For example, experts in the field of landscaping stressed the importance of both landscape and ecological aspects, while experts in environmental and other fields favored usability aspects. Importantly, respondents with more experience stressed the importance of ecological aspects. Respondents with fewer than five years of experience considered all factors equally, while those with 6-10 years of experience felt that usability was the most important consideration. 
Table 5. Relative importance of Tier 1 criteria based on respondent demographics.

\begin{tabular}{ccccccc}
\hline & Category & No & Ecological & Landscape & Usability & Economic \\
\hline Total & & 38 & 0.387 & 0.266 & 0.214 & 0.133 \\
Sex & Male & 23 & 0.362 & 0.281 & 0.224 & 0.133 \\
& Female & 15 & 0.426 & 0.242 & 0.199 & 0.133 \\
\multirow{5}{*}{ Age } & $20 \mathrm{~s}$ & 7 & 0.273 & 0.237 & 0.247 & 0.243 \\
& $30 \mathrm{~s}$ & 11 & 0.315 & 0.272 & 0.279 & 0.133 \\
& $40 \mathrm{~s}$ & 14 & 0.477 & 0.258 & 0.163 & 0.102 \\
Organization & 50s & 6 & 0.445 & 0.269 & 0.180 & 0.106 \\
& Government & 4 & 0.369 & 0.154 & 0.148 & 0.328 \\
Area & Academia & 8 & 0.376 & 0.240 & 0.266 & 0.117 \\
& Private Sector & 26 & 0.384 & 0.291 & 0.207 & 0.118 \\
Subject & Policy/Research & 12 & 0.387 & 0.215 & 0.227 & 0.171 \\
& Design/Construction & 26 & 0.384 & 0.291 & 0.207 & 0.118 \\
& Environment & 6 & 0.470 & 0.184 & 0.194 & 0.151 \\
& Landscape & 27 & 0.366 & 0.296 & 0.211 & 0.127 \\
Experience & Other & 5 & 0.394 & 0.219 & 0.247 & 0.140 \\
& Under 5 years & 8 & 0.293 & 0.217 & 0.225 & 0.265 \\
& 6-10 years & 8 & 0.283 & 0.285 & 0.338 & 0.094 \\
& 11-15 years & 8 & 0.450 & 0.234 & 0.185 & 0.131 \\
& More than 16 years & 14 & 0.457 & 0.282 & 0.159 & 0.102 \\
\hline
\end{tabular}

\subsection{Tier 2 Evaluation}

Of the Tier 2 categories relating to ecological aspects, air quality improvement $(0.307)$ was the most important criteria, followed by climate control functions (0.269), ecological conservation (0.230), and stormwater runoff management (0.194), as shown in Table 6. We attribute the high importance of air quality improvement to recent interest in reducing carbon emissions and fine particulates in urban areas. Moreover, respondents considered that the ecological aspects of UGI help to control urban climate issues, such as reduction of urban heat island effects.

Table 6. Evaluation of Tier 2 ecological criteria.

\begin{tabular}{cccc}
\hline Tier 1 Criterion & $\begin{array}{c}\text { Importance (Based on } \\
\text { Tier 1 Evaluation) }\end{array}$ & Tier 2 Criteria & $\begin{array}{c}\text { Importance (Based on } \\
\text { Tier 2 Evaluation) }\end{array}$ \\
\hline \multirow{3}{*}{ Ecological } & \multirow{2}{*}{0.387} & Climate Control & 0.269 \\
& & Air Quality Improvement & 0.307 \\
& & Stormwater runoff & 0.194 \\
& & Ecological conservation & 0.230 \\
\hline
\end{tabular}

Of the Tier 2 categories relating to landscape aspects, providing natural elements within an urban setting was considered to be the most important factor (0.407), followed by harmonizing with the surrounding environment (0.282), creating a featured landscape (0.161), and screening (0.151), as shown in Table 7 . This indicates that respondents valued 'naturalness' within artificial urban settings.

Table 7. Evaluation of Tier 2 landscape criteria.

\begin{tabular}{cccc}
\hline Tier 1 Criterion & $\begin{array}{c}\text { Importance (Based on } \\
\text { Tier 1 Evaluation) }\end{array}$ & Tier 2 Criteria & $\begin{array}{c}\text { Importance (Based on } \\
\text { Tier 2 Evaluation) }\end{array}$ \\
\hline \multirow{3}{*}{ Landscape } & \multirow{2}{*}{0.266} & Creating a featured landscape & 0.161 \\
& Harmonizing with & 0.282 \\
& & $\begin{array}{c}\text { Providing natural elements } \\
\text { within an urban setting }\end{array}$ & 0.407 \\
& Screening & 0.151 \\
\hline
\end{tabular}

Of the Tier 2 categories relating to usability aspects, accessibility (0.307) was the most important factor, followed by leisure and amenity (0.305), shelter (0.224), and educational functions (0.164), 
as shown in Table 8. This underscores the importance of UGI as a highly functional community space that needs to be easily accessible and amenable.

Table 8. Detailed evaluation of Tier 2 usability criteria.

\begin{tabular}{cccc}
\hline Tier 1 Criterion & $\begin{array}{c}\text { Importance (Based on } \\
\text { Tier 1 Evaluation) }\end{array}$ & Tier 2 Criteria & $\begin{array}{c}\text { Importance (Based on } \\
\text { Tier 2 Evaluation) }\end{array}$ \\
\hline \multirow{3}{*}{ Usability } & \multirow{2}{*}{0.214} & Accessibility & 0.307 \\
& & Leisure and amenity & 0.305 \\
& Educational functions & 0.164 \\
& Shelter & 0.224 \\
\hline
\end{tabular}

Of the Tier 2 categories relating to economic aspects, the planting cost $(0.356)$ was the most important factor, followed by maintenance (0.312), groundwork (0.191), and paving and other works (0.137), as shown in Table 9. The relative importance of planting and maintenance highlights the importance of these two factors in terms of the functionality and effectiveness of UGI. In particular, maintenance cost affects the continuity and long-term usability of UGI.

Table 9. Detailed evaluation Tier 2 economic criteria.

\begin{tabular}{cccc}
\hline Tier 1 Criterion & $\begin{array}{c}\text { Importance (Based on } \\
\text { Tier 1 Evaluation) }\end{array}$ & Tier 2 Criteria & $\begin{array}{c}\text { Importance (Based on } \\
\text { Tier 2 Evaluation) }\end{array}$ \\
\hline \multirow{3}{*}{ Economic } & \multirow{2}{*}{0.133} & Cost for groundworks & 0.196 \\
& & Cost for planting & 0.356 \\
& Cost for Paving & 0.137 \\
& and other works & 0.312 \\
\hline
\end{tabular}

When all of the Tier 2 elements were considered together, air quality improvement (0.119) was the most important factor, followed by providing natural elements within an urban setting $(0.108)$ (Table 10). These factors illustrate the significance of conventional UGI values, such as the provision of natural elements within an urban setting. At the same time, survey respondents also acknowledged the functional benefits of UGI, such as improving air quality.

Table 10. Priority rankings of Tier 2 evaluation criteria.

\begin{tabular}{ccc}
\hline Tier 2 Criteria & Weighed Value & Priority \\
\hline Air quality improvement & 0.119 & 1 \\
Providing natural elements within urban settings & 0.108 & 2 \\
Climate control & 0.104 & 3 \\
Ecological conservation & 0.089 & 4 \\
Stormwater runoff & 0.075 & 5 \\
Harmonizing with the surrounding environment & 0.075 & 5 \\
Accessibility & 0.066 & 7 \\
Providing leisure and amenity & 0.065 & 8 \\
Shelter & 0.048 & 9 \\
Planting cost & 0.047 & 10 \\
Creating a featured landscape & 0.043 & 11 \\
Maintenance cost & 0.042 & 12 \\
Screening & 0.040 & 13 \\
Providing educational functions & 0.035 & 14 \\
Groundworks cost & 0.026 & 15 \\
Paving and other works cost & 0.018 & 16 \\
\hline
\end{tabular}

The importance of the Tier 1 ecological criteria is recognized in the relative importance of Tier 2 ecological factors such as ecological conservation (0.089) and improving stormwater runoff 
(0.075). Furthermore, the landscape criteria, harmonizing with the surrounding environment (0.075), accessibility (0.066), and leisure and amenity were also important. Economic aspects were the least important Tier 1 criteria, and this was reflected in the relatively low importance of the Tier 2 criteria of groundwork (0.026) and paving and other works (0.018).

Analyzing the weighted values of the Tier 2 categories revealed some interesting results. For example, as highlighted in Table 11 below, based on the age and field of survey respondents, air quality improvement was important to respondents in their 40s (0.155) and 50s (0.158), with an environment background (0.137) and over 16 years of experience (0.168). Survey respondents with more experience had higher expectations with respect to improving urban air quality using GI.

Government respondents and those with 11-15 years of experience valued the climate control aspects of UGI highly ( 0.136 and 0.147 , respectively), while private sector respondents valued providing natural elements within an urban setting (0.117). Accessibility (0.119) and leisure and amenity (0.104) were considered important by respondents with 6-10 years of experience, and maintenance cost was important to government respondents (0.157). The high importance of the maintenance cost within this group are expected given that the government sector is responsible for the ongoing maintenance of UGI.

As mentioned above, the GI priorities considered important among experts were almost similar, but there were differences in the detailed factors depending on age, gender, and occupation. It is expected that the derived priority results will support UGI planning and design decisions more quickly. However, due to the nature of GI, it may be difficult to generalize the results for application in any location [44]. Depending on the area, climate, and size where the GI is created, the applied priorities may differ, and this should be specified and developed through further research. 
Table 11. Detailed evaluation of Tier 2 aspects based on respondent demographics.

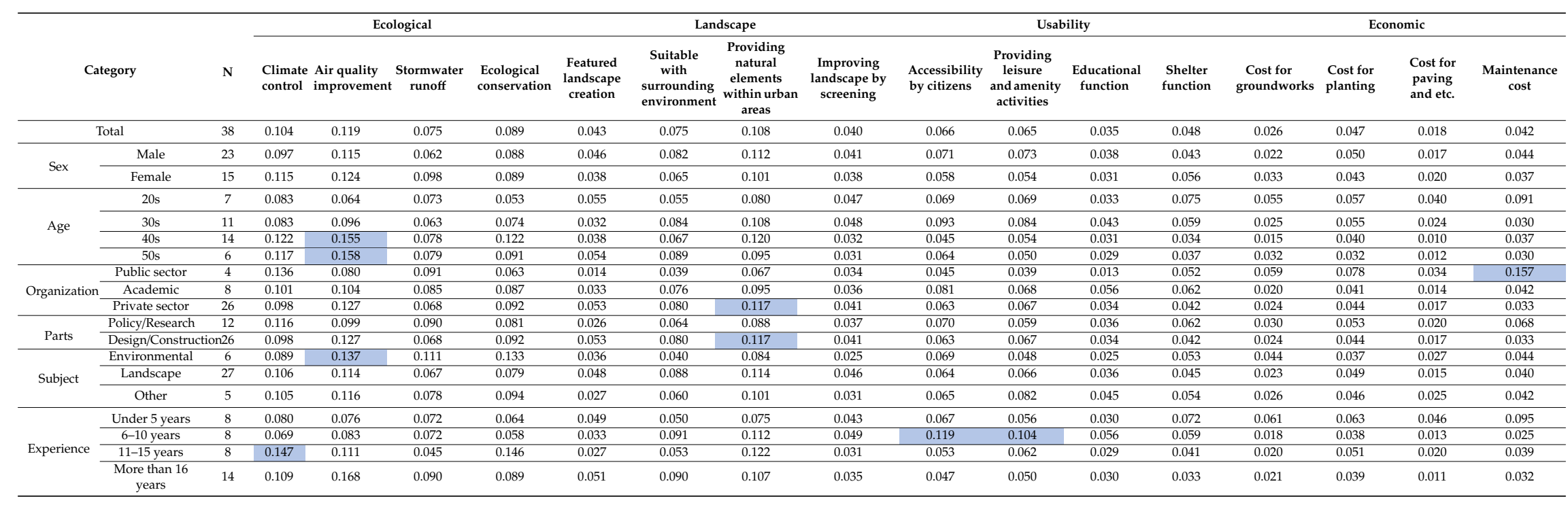




\section{Conclusions}

UGI plays a key role in modern society by improving the quality of life of communities and enhancing social cohesion. However, there has been limited research regarding the methods and considerations needed to create effective UGI in today's rapidly evolving societies. Instead, UGI development has been focused on location, scale, and cost rather than developing a systematic approach to better serve the community. This study aimed to identify the most important considerations when developing UGI and to prioritize these considerations to create an effective urban environment.

The AHP method reflects the multi-layered structure of complex decision-making and can be applied in uncertain conditions or where several assessment criteria are required. In this study, questionnaires were employed using AHP methodology to examine the decision criteria of GI experts in terms of design priorities. Four primary criteria and 16 detailed subcategories were derived from a review of current literature. Questionnaires were completed by 57 experts, who evaluated the weight of each category using a 9-point scale. The categories were than ranked based on their relative order of importance.

Results showed that ecological functions were considered by most experts to be the key priority for UGI development. This was followed by air quality improvement, providing naturalness within urban areas, climate control, conservation of urban ecology, and stormwater management. Harmonization with the surroundings, accessibility, and leisure and recreation were also identified as important criteria. Generally, economic factors were not given a high priority in UGI development because experts tended to focus on the benefits of UGI as opposed to construction and maintenance costs. Respondents that prioritized planting and maintenance cost tended to work in the government sector.

In this study, we prioritized aspects of the UGI design and construction process using a literature review, expert interviews, and a hierarchal analysis. Our results provide a roadmap to facilitate more rapid decision-making for UGI development by underscoring the key priorities for UGI. Furthermore, we hope that our findings will help to facilitate a holistic approach to UGI planning and development in the future. Opportunities for further research include ongoing analysis and mediation between experts, as well as potential field applications. To achieve this, additional empirical evidence on the effects of GI would be necessary for policy implementation in the design and construction phases.

Author Contributions: Study design conceptualization, Y.S. and K.A.; writing-original draft preparation, Y.S.; writing-review and editing, S.K. and K.A.; supervision, S.-W.L. All authors have read and agreed to the published version of the manuscript.

Funding: This research received no external funding.

Acknowledgments: This paper was supported by Konkuk University in 2017.

Conflicts of Interest: The authors declare no conflict of interest.

\section{References}

1. UK Green Building Council. Demystifying Green Infrastructure; UK Green Building Council: London, UK, 2015.

2. Berardi, U.; GhaffarianHoseini, A.; Ali, G. State-of- the-art analysis of the environmental benefits of green roofs. J. Appl. Energy 2013, 115, 411-428. [CrossRef]

3. Vandermeulen, V.; Verspecht, A.; Vermeire, B.; Van Huylenbroeck, G.; Gellynck, X. The use of economic valuation to create public support for green infrastructure investments in urban areas. Landsc. Urban Plan. 2011, 103, 198-206. [CrossRef]

4. Wang, Y.-C.; Shen, J.-K.; Xiang, W.-N. Ecosystem service of green infrastructure for adaptation to urban growth: Function and configuration. Ecosyst. Health Sustain. 2018, 4, 132-143. [CrossRef]

5. Engström, G.; Gren, A. Capturing the value of green space in urban parks in a sustainable urban planning and design context: Pros and cons of hedonic pricing. Ecol. Soc. 2017, 22, 21. [CrossRef]

6. Hewitt, C.N.; Ashworth, K.; MacKenzie, A.R. Using green infrastructure to improve urban air quality (GI4AQ). Ambio 2020, 49, 62-73. [CrossRef] [PubMed] 
7. Parker, J.; Zingoni de Baro, M.E. Green Infrastructure in the Urban Environment: A Systematic Quantitative Review. Sustainability 2019, 11, 3182. [CrossRef]

8. Colding, J. The role of ecosystem services in contemporary urban planning. Urban Ecol. Patterns Process. Appl. 2011, 228-237.

9. Ahern, J.; Cilliers, S.; Niemelä, J. The concept of ecosystem services in adaptive urban planning and design: A framework for supporting innovation. Landsc. Urban Plan. 2014, 125, 254-259. [CrossRef]

10. Benedict, M.; McMahon, E. Green Infrastructure: Smart Conservation for the 21st Century. Renew. Resour. J. 2002, 20, 12-17.

11. Kumar, P.; Druckman, A.; Gallagher, J.; Gatersleben, B.; Allison, S.; Eisenman, T.S.; Hoang, U.; Hama, S.; Tiwari, A.; Sharma, A.; et al. The nexus between air pollution, green infrastructure and human health. Environ. Int. 2019, 133, 105181. [CrossRef]

12. Matthews, T.; Lo, A.Y.; Byrne, J.A. Reconceptualizing green infrastructure for climate change adaptation: Barriers to adoption and drivers for uptake by spatial planners. Landsc. Urban Plan. 2015, 138, 155-163. [CrossRef]

13. Lovell, S.T.; Taylor, J.R. Supplying urban ecosystem services through multifunctional green infrastructure in the United States. Landsc. Ecol. 2013, 28, 1447-1463. [CrossRef]

14. Albert, C.; Von Haaren, C. Implications of Applying the Green Infrastructure Concept in Landscape Planning for Ecosystem Services in Peri-Urban Areas: An Expert Survey and Case Study. Plan. Pract. Res. 2017, 32, 227-242. [CrossRef]

15. Jim, C.Y.; Chen, W.Y. Perception and Attitude of Residents toward Urban Green Spaces in Guangzhou (China). Environ. Manag. 2006, 38, 338-349. [CrossRef]

16. Tyrväinen, L.; Silvennoinen, H.; Kolehmainen, O. Ecological and aesthetic values in urban forest management. Urban For. Urban Green. 2003, 1, 135-149. [CrossRef]

17. Zhou, X.; Parves Rana, M. Social benefits of urban green space: A conceptual framework of valuation and accessibility measurements. Manag. Environ. Qual. Int. J. 2012, 23, 173-189. [CrossRef]

18. Hartig, T.; Mitchell, R.; de Vries, S.; Frumkin, H. Nature and Health. Annu. Rev. Public Health 2014, 35, 207-228. [CrossRef]

19. Grahn, P.; Stigsdotter, U.A. Landscape planning and stress. Urban For. Urban Green. 2003, 2, 1-18. [CrossRef]

20. Schilling, J.; Logan, J. Greening the Rust Belt: A Green Infrastructure Model for Right Sizing America's Shrinking Cities. J. Am. Plan. Assoc. 2008, 74, 451-466. [CrossRef]

21. Ahern, J. From fail-safe to safe-to-fail: Sustainability and resilience in the new urban world. Landsc. Urban Plan. 2011, 100, 341-343. [CrossRef]

22. Kim, D.; Song, S.-K. Case Study on Community Benefits of Green Infrastructure. J. Korea Plan. Assoc. 2017, 52, 185. [CrossRef]

23. Norton, B.A.; Coutts, A.M.; Livesley, S.J.; Harris, R.J.; Hunter, A.M.; Williams, N.S.G. Planning for cooler cities: A framework to prioritise green infrastructure to mitigate high temperatures in urban landscapes. Landsc. Urban Plan. 2015, 134, 127-138. [CrossRef]

24. Bowler, D.E.; Buyung-Ali, L.; Knight, T.M.; Pullin, A.S. Urban greening to cool towns and cities: A systematic review of the empirical evidence. Landsc. Urban Plan. 2010, 97, 147-155. [CrossRef]

25. Erell, E. The Application of Urban Climate Research in the Design of Cities. Adv. Build. Energy Res. 2008, 2, 95-121. [CrossRef]

26. Porse, E. Open data and stormwater systems in Los Angeles: Applications for equitable green infrastructure. Local Environ. 2018, 23, 505-517. [CrossRef]

27. Kambites, C.; Owen, S. Renewed prospects for green infrastructure planning in the UK 1. Plan. Pract. Res. 2006, 21, 483-496. [CrossRef]

28. Hansen, R.; Pauleit, S. From Multifunctionality to Multiple Ecosystem Services? A Conceptual Framework for Multifunctionality in Green Infrastructure Planning for Urban Areas. Ambio 2014, 43, 516-529. [CrossRef]

29. Haq, S.M.A. Urban Green Spaces and an Integrative Approach to Sustainable Environment. J. Environ. Prot. 2011, 2, 601-608. [CrossRef]

30. EPA. The Causal Analysis/Diagnosis Decision Information System (CADDIS); EPA: New York, NY, USA, 2017.

31. Alves, A.; Patiño Gómez, J.; Vojinovic, Z.; Sánchez, A.; Weesakul, S. Combining Co-Benefits and Stakeholders Perceptions into Green Infrastructure Selection for Flood Risk Reduction. Environments 2018, 5, 29. [CrossRef] 
32. Mell, I.C. Can green infrastructure promote urban sustainability? Proc. Inst. Civ. Eng. Eng. Sustain. 2009, 162, 23-34. [CrossRef]

33. Mell, I.C. Green Infrstructure: Concepts and planning. FORUM ejournal 2008, 8, 69-80.

34. Martinelli, L.; Battisti, A.; Matzarakis, A. Multicriteria analysis model for urban open space renovation: An application for Rome. Sustain. Cities Soc. 2015, 14, e10-e20. [CrossRef]

35. Xu, C.; Tang, T.; Jia, H.; Xu, M.; Xu, T.; Liu, Z.; Long, Y.; Zhang, R. Benefits of coupled green and grey infrastructure systems: Evidence based on analytic hierarchy process and life cycle costing. Resour. Conserv. Recycl. 2019, 151, 104478. [CrossRef]

36. Yang, J.K.; Lee, C.G.; Jeon, J.H.; Lee, H.K. Selection and management factor analysis of urban infrastructure for U-City construction. KSCE J. Civ. Eng. 2013,17, 1637-1643. [CrossRef]

37. Haider, H.; Chumman, A.R.; Al-Salamah, I.S.; Ghazaw, Y.; Abdel-Maguid, R.H. Sustainability Evaluation of Rainwater Harvesting-Based Flood Risk Management Strategies: A Multilevel Decision-Making Framework for Arid Environments. Arab. J. Sci. 2019, 44, 8465-8488. [CrossRef]

38. Saaty, T.L. The Analytic Hierarchy Process; The McGraw Hill Building: New York, NY, USA, 1980.

39. Saaty, T.L.; Vargas, L.G. Models, Methods, Concepts \& Applications of the Analytic Hierarchy Process; Springer: New York, NY, USA, 2012.

40. Erden, T.; Karaman, H. Analysis of earthquake parameters to generate hazard maps by integrating AHP and GIS for Küçükçekmece region. Nat. Hazards Earth Syst. Sci. 2012, 12, 475-483. [CrossRef]

41. Song, K.-W.; Lee, Y. Re-scaling for Improving the Consistency of the AHP Method. Soc. Sci. Res. Rev. 2013, 29, 271-288.

42. Kim, B. Analytic Hierarchy Process (AHP) Analysis Method; Kim's inforamtion: Seoul, Korea, 2015.

43. Ahn, S.H.; Shim, S.D.; Jang, J.K.; Kim, S.Y. General Guidelines for Preliminary Feasibility Studies, 5th ed.; Korea Development Institute: Sejong, Korea, 2008.

44. Kim, D.; Song, S.-K. The Multifunctional Benefits of Green Infrastructure in Community Development: An Analytical Review Based on 447 Cases. Sustainability 2019, 11, 3917. [CrossRef]

(C) 2020 by the authors. Licensee MDPI, Basel, Switzerland. This article is an open access article distributed under the terms and conditions of the Creative Commons Attribution (CC BY) license (http://creativecommons.org/licenses/by/4.0/). 